\title{
The \\ Cat Island \\ Turtle
}

\section{James Perran Ross}

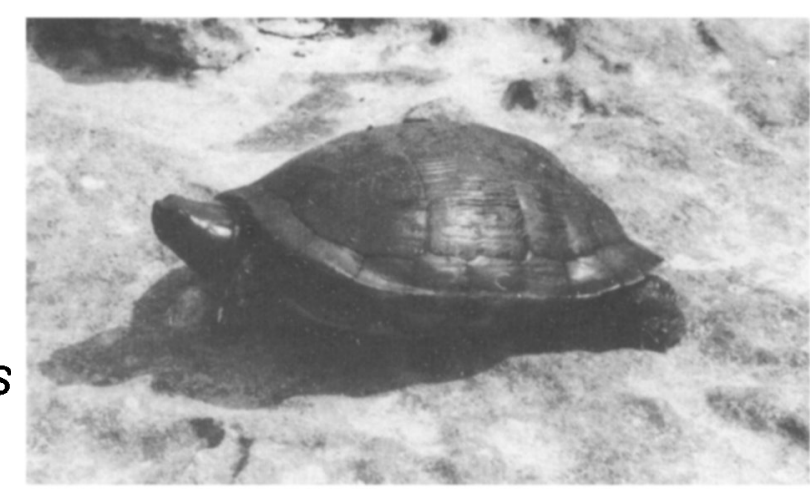

Four rare Pseudemys felis were captured and eight more turtles seen in a twoday survey on Cat Island, Bahamas, in March, 1981. A breeding population of this species persists in an area of $2.5 \mathrm{sq} \mathrm{km}$. Cat island turtles are captured for pets and food by local people and are threatened by potential road building and land development.

The Cat Island turtle Pseudemys felis was described in 1935 from specimens obtained from small freshwater ponds at Tea Bay on the west coast of Cat Island, Bahamas. ${ }^{1}$ Subsequent reports suggested that it was restricted to a few ponds that periodically dry up, and that the turtles were captured by local people for food and pets. Brief notes on its biology and habitat have been published, ${ }^{2,5}$ but details of its biology, numbers and distribution remain poorly known. Campbell ${ }^{4}$ reported that in 1975 the ponds were nearly dry and no live turtles were found. The taxonomic status of this isolated population is uncertain. Some authorities lump all the Antillean freshwater turtles as subspecies of $P$. terrapen, ${ }^{6}$ others consider each insular variety to be separate. ${ }^{3}$ Pseudemys felis is similar to $P$. terrapen from Jamaica and notably different from $P$. malone $i$ on Inagua and $P$. decussata from Cuba. It is a morphologically distinct and isolated population occupying a restricted range and subject to human predation. Information on its status is clearly required.

In March 1981 I spent two days at Cat Island surveying the type locality of $P$. felis and evaluating its present status with students from the research vessel Regina Maris.

The type locality is near Tea Bay on the west Coast, at lat. $24^{\circ} 23.5^{\prime} \mathrm{N}$, long. $75^{\circ} 31.8^{\prime} \mathrm{W}, 32 \mathrm{~km}$ south of the northern end of Cat Island. The turtles are found in shallow freshwater ponds between Tea Bay and the village of Knowles, $4.0 \mathrm{~km}$ to the south. The ponds occur in depressions in the oolitic limestone and lie in a band less than $1 \mathrm{~km}$ wide and $2.5 \mathrm{~km}$ long, with open water in at least nine of them covering a total area estimated at $1.3 \mathrm{ha}$. They are all within $250 \mathrm{~m}$ of the sea and separated from it by a rocky limestone littoral and fixed dune on which runs a single-lane, tarmac road. Surrounding them is a thick growth of buttonwood Conocarpus erecta and sea grape Cocoloba sp. concealing other pools.

The main ponds range in size from about $80-7500 \mathrm{sq} \mathrm{m}$ with $10-30 \mathrm{~cm}$ maximum depth of fresh water, and a further $20-50 \mathrm{~cm}$ of fine silty marl covering the limestone bottom. At the time of our visit they appeared to be $20 \mathrm{~cm}$ below their maximum depth. Their outlines are irregular and parts of the margins are smooth undercut limestone. All the ponds support algae (Chara zeylanica) and the shallower warmer ones also contained Nitella hyalina and the grass Ruppia maritima. 
We searched the seven largest ponds, alternating quiet watches for surfacing turtles with wading in the mud and searching beneath vegetation and rock overhangs. Captured turtles were photographed, measured, weighed, held overnight separately and released at their point of capture. The turtles are both shy and fast moving and difficult to catch in the turbid water but in the two days we were able to catch four by hand and deduce the presence of at least eight more from sightings and tracks of different sizes. All 12 were in ponds or parts of ponds that were deeper than average $(30 \mathrm{~cm}+)$, with temperatures of $24^{\circ} \mathrm{C}$ in their deep muddy sediments in contrast with $26-27^{\circ}$ in the shallower pools. No turtles were found buried in the mud, but one turtle was caught underwater deep within a rock overhang in a deep part of an otherwise shallow pond. We found abundant evidence from tracks that the turtles move from pond to pond.

The turtles are well known to local inhabitants, who call them 'Peter'. They told us that the ponds we examined are the only natural habitat, although many turtles have been caught and introduced into freshwater pools near houses on the island. They are only rarely taken for food but local children keep them as pets. We were given two of a group of four such pets, survivors of an original nine that were kept in a well. They were also said to be sent as pets to Nassau. People at Knowles say the turtles eat a variety of vegetable matter, as reported by Barbour and Shreve. ${ }^{2}$ Two of our wild caught turtles defecated masses of plant epidermis when held overnight. We were told that on rainy nights they are encountered on the road and in the bush, far from the ponds. Schoolchildren reported finding hatchlings in the rainy season (June-August), after the turtles lay their eggs in the mud at the margins of the ponds. Schoolchildren are the turtles' major predator.

\section{Status of the Population}

We cannot estimate the number of $P$. felis from our survey, and local claims that the turtle is abundant must be treated with care. However, we recorded at least 12 individuals in the main ponds and it seems likely that many more find refuge in the small sinks and holes that abound in this coastal strip. Their reported appearance after rain suggests a large reservoir of turtles, and there must be a considerable number held in domestic water supplies, although whether they are a part of the breeding population we cannot say. The size distribution and sex ratio of our captives and the reports of juveniles occurring in June-August all suggest that the population continues to reproduce successfully, although the data base is small. While unable to give a population estimate, at least we can say that the turtle is not extinct.

There is an area of approximately $2.5 \mathrm{sq} \mathrm{km}$ with an unknown amount of suitable freshwater habitat, but the main ponds, which are the main available freshwater resource, total only $1.3 \mathrm{ha}$. However, it seems likely that the persistence of this population is dependent on the existence of deep, sheltered refugia that retain water as the larger ponds dry up.

\section{Threats}

We identified three threats to this vulnerable population: local use, road building and land development. While capture for food is reported to be declining, it is clear that the local people, particularly young boys, prey extensively on the turtles, and most of those caught are lost to the breeding population. One young man reported catching 15 in one day, and another had nine, of which five died. 
The author searching for turtles at Tea Bay. His right leg indicates the depth of the water and his left leg that of the mud

The position of the remaining ponds next to the only north/south road on Cat Island poses a severe threat as the island develops. A minor change in drainage, road-widening or the use of heavy machinery around the ponds could irreparably damage the turtles' only known habitat. Because the ponds are close to the sea, a drainage change could result in flooding with sea water.

The presence of fresh water and potentially fertile soil in and around the ponds put them at risk for development. Many houses and fields in the area are abandoned and in disrepair; however, some land is being developed for tourism and farming, some new houses are being built, and two areas, about 100ha each, between Tea Bay and Knowles have been cleared by bulldozer for farming.

Conserving this turtle will require a simultaneous programme of local education and scientific study. Population size, movements, reproduction and natural mortality need to be evaluated. A tagging study utilizing young local assistants would be a useful start. Because the turtles occur in such a restricted area, the possibility of land acquisition or protection for the whole habitat is feasible.

\section{Acknowledgments}

This survey was supported by the New York Zoological Society, WWF-US and the Bahamas National Trust. The Ocean Research and Education Society, Boston, provided transport, accommodation and logistic support in the Bahamas. I am grateful to students of Regina Maris Expedition No. 26 for their assistance. This is Misc. Contribution No. 2 of the IUCN/SSC Freshwater Turtle Specialist Group. Dr P. Stevens of the Harvard University Herbarium kindly identified the aquatic plants.

\section{References}

1. BARBOUR, T. 1935. A new Pseudemys from Cat Island, Bahamas. Occasional Papers Boston Soc. Nat. Hist. 8: 205-6.

2. BARBOUR, T. and B. SHREVE. 1935. Concerning some Bahamian Reptiles, with notes of the Fauna. Proc. Bost. Soc. Nat. Hist. 40, 5: 347-66.

3. BARBOUR, T. and A.F. CARR. 1940. Antillean Terrapins. Mem. Mus. Comp. Zool. 54, 5: 381-415.

4. CAMPBELL, D. 1978. The Ephemeral Islands. Macmillan Press, pp. 70-2.

5. HODSDON, L.A. and J.F.W. PEARSON. 1943. Notes on the discovery and biology of two Bahaman fresh water turtles of the genus Pseudemys. Proc. Fla. Acad. Sci. 6: 17-23.

6. WERMUTH, H. and R. MERTENS. 1977. 'Testudines, Crocodilia, Rhynchocephalia. Das Tierreich 100: 1-174. Dr J.P. Ross, Museum of Comparative Zoology, Harvard University, Cambridge, MA 02138,
USA. 